\title{
Evaluation of Radiosurgery Target Volume Definition for Tectal Gliomas with Incorporation of Magnetic Resonance Imaging (MRI): An Original Article
}

\author{
Selcuk Demiral, Murat Beyzadeoglu, Ferrat Dincoglan and Omer Sager* \\ Department of Radiation Oncology; University of Health Sciences, Turkey \\ *Corresponding author: Omer Sager, University of Health Sciences, Gulhane Medical Faculty, Department of Radiation \\ Oncology, Turkey
}

ARTICLE INFO

Received: 陆 April 14, 2020

Published: 幽 April 22, 2020

Citation: Selcuk D, Murat B, Ferrat D, Omer S. Acute Onset Paraplegia Due to Thoracic Angiolipoma: A Case Report and Review of the Literature. Biomed J Sci \& Tech Res 27(2)-2020. BJSTR. MS.ID.004461.

Keywords: Tectal glioma; Radiosurgery; Magnetic resonance imaging (MRI)

Abbreviations: MRI: Magnetic Resonance Imaging; CT: Computed Tomography; RT: Radiation Therapy; IGRT: Image Guided Radiation Therapy; SRS: Stereotactic Radiosurgery; SBRT: Stereotactic Body Radiotherapy; HFSRT: Hypo fractionated Stereotactic Radiation Therapy; AMOA : Arc Modulation Optimization Algorithm

\begin{abstract}
Objective: Tectal gliomas are rare, typically low grade tumours located in close vicinity of the cerebral aqueduct. These lesions in the tectal region of the mesencephalon are considered as a distinctive subgroup of brainstem gliomas with respect to their unique radiological, pathological, and clinical features. Affected patients generally have a history of headache and may have other symptoms such as nausea, vomiting, gait and visual disturbances. Although benign behaviour is not uncommon for tectal gliomas, therapeutic options including surgical interventions, systemic agents, and radiation therapy (RT) may be utilized for management of selected patients in the upfront or salvage settings. In this study, we evaluate incorporation of MRI for radiosurgery treatment planning of tectal gliomas.
\end{abstract}

Materials and Methods: A comparative evaluation of radiosurgery target volume with and without incorporation of MRI has been performed. Ground truth target volume serving as the reference has been determined by board certified radiation oncologists after comprehensive evaluation, collaboration, colleague peer review and consensus.

Results: Definition of target volume by use of CT-only imaging and CT-MR fusionbased imaging for linear accelerator (LINAC)-based radiosurgery of tectal glioma has been comparatively assessed in this study. Ground truth target volume which has been determined by the board-certified team of radiation oncologists after detailed evaluation, collaboration, colleague peer review and consensus has been found to be identical to target determination by use of CT-MR fusion based imaging.

Conclusion: Incorporation of MRI into target definition process may improve radiosurgery treatment planning for tectal gliomas despite the need for further supporting evidence.

\section{Introduction}

Tectal gliomas are rare, typically low-grade tumours located in close vicinity of the cerebral aqueduct. These lesions in the tectal region of the mesencephalon are considered as a distinctive subgroup of brainstem gliomas with respect to their unique radiological, pathological, and clinical features. Focal, intrinsic lesions of the tectum are typically located at the periaqueductal region, and contrast enhancement is uncommon. Primary symptoms suffering from tectal gliomas occur due to obliteration of aqueduct of Sylvius resulting in noncommunicating hydrocephalus. Given the typically indolent nature, tectal gliomas lead to symptoms associated with late-onset hydrocephalus. Affected patients generally have a history of headache and may have other symptoms such as nausea, vomiting, gait and visual disturbances. Although benign behaviour is not uncommon for tectal gliomas, these tumours have been described as smallest lesions in the body leading to death [1-3]. Computed tomography (CT) may aid in detection of hydrocephalus, however, may not be capable of revealing the tectal lesion in about half of patients suffering from tectal glioma $[3,4]$. Majority of these tumours are visualized as periaqueductal, dorsally exophytic, well-circumscribed, non-enhancing, intrinsic focal lesions of the tectum extending from the quadrigeminal plate 
with T2-hyperintensity and T1-isointensity on Magnetic Resonance Imaging (MRI) [4-8]. Pineal cysts and germ cell tumours may be considered for differential diagnosis of tectal gliomas.

Given the indolent nature of these tumours, observation may be an option in selected patients. However, therapeutic options including surgical interventions, systemic agents, and radiation therapy (RT) have been utilized for management of tectal gliomas as upfront or salvage therapies [2,3,9-17]. Contemporary RT techniques and radiosurgery in the forms of Stereotactic Radiosurgery (SRS), Stereotactic Body Radiotherapy (SBRT) and Hypo fractionated Stereotactic Radiation Therapy (HFSRT) may be utilized for focused irradiation of several central nervous system disorders as well as tumours located throughout the human body [18-40]. Target volume definition is an indispensable part of radiosurgery given that smaller volumes are treated to higher doses per fraction. Treatment planning for radiosurgery has been traditionally based on CT-simulation images of the patient acquired in treatment position. In this study, we assess the incorporation of MRI for radiosurgery treatment planning of tectal gliomas.

\section{Materials and Methods}

Determination of radiosurgery target volume with and without incorporation of MRI has been assessed for linear accelerator (LINAC)-based radiosurgery of tectal glioma in this study. Ground truth target volume serving as the reference has been determined by board certified radiation oncologists after comprehensive evaluation, collaboration, and consensus. Informed consents have been acquired prior to treatment, and management of patients with radiosurgery has been decided by a multidisciplinary team of experts from neurosurgery, neuroradiology, and radiation oncology. Detailed evaluation has been performed regarding the lesion size, location, patient symptomatology and preferences. CT-simulation to be used for radiosurgery treatment planning has been performed at CT-simulator (GE Lightspeed RT, GE Healthcare, Chalfont St. Giles, UK) available at our institution. Planning CT images have been acquired and then transferred to the delineation workstation (SimMD, GE, UK) for contouring of treatment volumes and critical organs. Target volume determination for radio surgical management has been performed by use of CT simulation images only or fused CT and T1 gadolinium-enhanced MR images. Target determination with CT only and by incorporation of CT-MR fusion has been comparatively evaluated. Determination of ground truth target volume has been performed by board certified radiation oncologists after detailed assessment, collaboration, colleague peer review and consensus for actual treatment and comparison purposes.

\section{Results}

Definition of target volume by use of CT-only imaging and CTMR fusion-based imaging has been comparatively assessed in this study. Ground truth target volume which has been determined by the board-certified team of radiation oncologists after detailed evaluation, collaboration, colleague peer review and consensus has been found to be identical to target determination by use of CT-MR fusion-based imaging.

Radiosurgery treatment planning has been accomplished by ERGO ++ (CMS, Elekta, UK) radiosurgery planning system. A single 360-degree arc, double 360-degree arcs, or five 180-degree arcs have been used in radiosurgery planning to achieve optimal target coverage and normal tissue sparing. Treatment delivery has been performed by Synergy (Elekta, UK) LINAC available at our institution. Determination of the target volume on planning CT and MR images has been optimized by selecting the appropriate windows and levels for radiosurgery planning. Precise delineation of target volume and critical structures has been provided by supplementing the axial planning CT images with sagittal and coronal images. Target volume coverage and normal tissue sparing has been optimized by use of Arc Modulation Optimization Algorithm (AMOA). Figure 1 shows axial planning CT image and Figure 2 shows the axial MR image of a patient with tectal glioma.

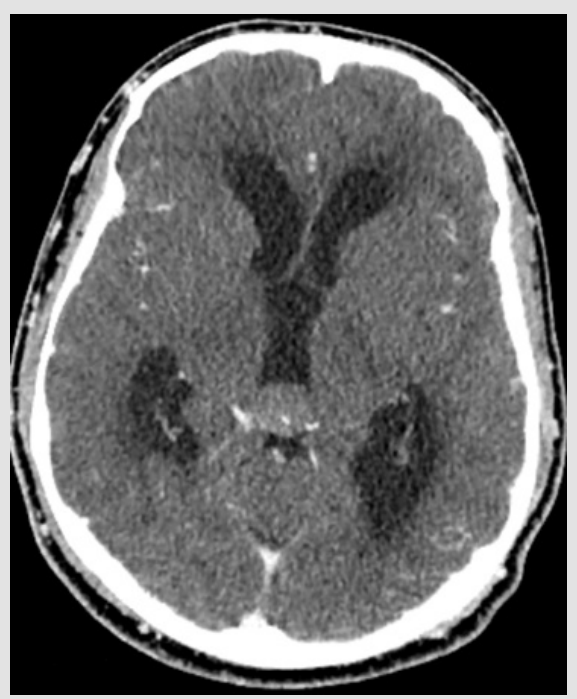

Figure 1: Axial CT image of a patient with tectal glioma. 


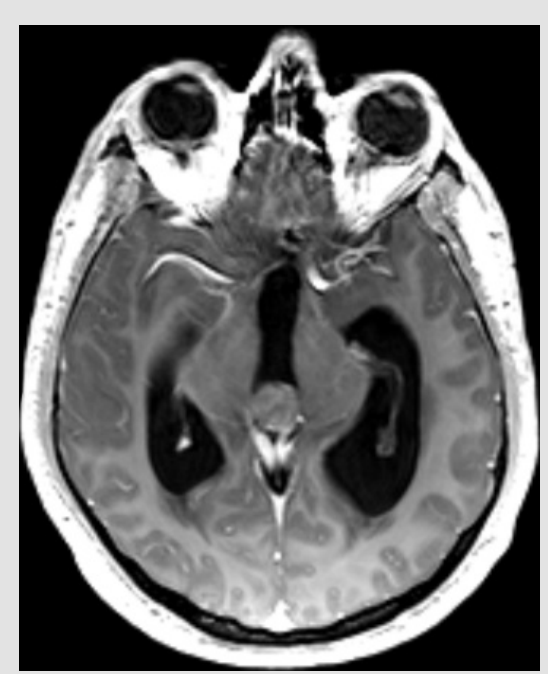

Figure 2: Axial MR image of a patient with tectal glioma.

\section{Discussion}

Tectal glioma is considered as a benign subgroup of brainstem gliomas with an indolent disease course. Nevertheless, management of patients may be required for relief of symptoms arising from hydrocephalus. RT may be used as part of management for tectal gliomas. There have been significant improvements in the discipline of radiation oncology recently such as Image Guided Radiation Therapy (IGRT), Adaptive Radiation Therapy (ART), Intensity Modulated Radiation Therapy (IMRT), Breathing Adapted Radiation Therapy (BART), and stereotactic irradiation with SRS, HFSRT, and SBRT [41-47]. Radiosurgery has been used for treatment of tectal gliomas with encouraging outcomes [16,17]. Smaller lesions are well suited for radiosurgery given the higher delivered dose per fraction. Radiosurgery may be exploited for its improved precision in RT delivery with stereotactic localization and optimized normal tissue sparing due to steep dose gradients around the target volume. However, it is more sensitive to delineation errors since typically little or no margin around the target volume exists. In this context, definition of target volume for radiosurgery is a highly important part of successful patient management.

While determination of larger target volumes may result in untowards treatment related toxicity, smaller than actual target volumes may lead to geographical misses with resultant treatment failure. Multimodality imaging may improve target localization, and the use of fused CT and MR images may supplement each other for precision in delineation of target volume for radiosurgery. Utility of multimodality imaging for radiosurgery treatment planning for tectal gliomas has been poorly addressed in the literature. In this context, our study adds to the existing literature and supports the incorporation of MRI for improved radiosurgery treatment planning for tectal gliomas consistent with another studies [48-59]. In conclusion, incorporation of MRI into target definition process may improve radiosurgery treatment planning for tectal gliomas despite the need for further supporting evidence.

\section{References}

1. Bowers DC, Georgiades C, Aronson LJ, Carson BS, Weingart JD, et al. (2000) Tectal gliomas: natural history of an indolent lesion in pediatric patients. Pediatr Neurosurg 32(1): 24-29.

2. Dağlioğlu E, Cataltepe O, Akalan N (2003) Tectal gliomas in children: the implications for natural history and management strategy. Pediatr Neurosurg 38(5): 223-231.

3. Stark AM, Fritsch MJ, Claviez A, Dörner L, Mehdorn HM (2005) Management of tectal glioma in childhood. Pediatr Neurol 33(1): 33-38.

4. Bognar L, Turjman F, Villanyi E, Mottolese C, Guyotat J, et al. (1994) Tectal plate gliomas. Part II: CT scans and MR imaging of tectal gliomas. Acta Neurochir (Wien) 127(1-2): 48-54.

5. Pollack IF, Pang D, Albright AL (1994) The long-term outcome in children with late-onset aqueductal stenosis resulting from benign intrinsic tectal tumors. J Neurosurg 80(4): 681-688.

6. Barkovich AJ, Newton TH (1989) MR of aqueductal stenosis: evidence of a broad spectrum of tectal distortion. AJNR Am J Neuroradiol 10(3): 471-476.

7. Friedman DP (1992) Extrapineal abnormalities of the tectal region: MR imaging findings. AJR Am J Roentgenol 159(4): 859-866.

8. Sun B, Wang CC, Wang J (1999) MRI characteristics of midbrain tumours. Neuroradiology 41(3): 158-162.

9. Ramina R, Coelho Neto M, Fernandes YB, Borges G, Honorato DC, et al. (2005) Intrinsic tectal low grade astrocytomas: is surgical removal an alternative treatment? Long-term outcome of eight cases. Arq Neuropsiquiatr 63(1): 40-45.

10. Burzynski SR, Burzynski GS, Janicki TJ, Marszalek A (2015) Complete response and long-term survival ( $>20$ years) of a child with tectal glioma: a case report. Pediatr Neurosurg 50(2): 99-103.

11. Griessenauer CJ, Rizk E, Miller JH, Hendrix P, Tubbs RS, et al. (2014) Pediatric tectal plate gliomas: clinical and radiological progression, MR imaging characteristics, and management of hydrocephalus. J Neurosurg Pediatr 13(1): 13-20.

12. Shah A, Jung H (2015) Surgical approach to low-grade tectal gliomas. Acta Neurochir (Wien) 157(8): 1373-1374.

13. Mohme M, Fritzsche FS, Mende KC, Matschke J, Löbel U, et al. (2018) Tectal gliomas: assessment of malignant progression, clinical management, 
and quality of life in a supposedly benign neoplasm. Neurosurg Focus 44(6): E15.

14. Kaufmann A, Gerber NU, Kandels D, Azizi AA, Schmidt R, et al. (2018) Management of Primary Tectal Plate Low-Grade Glioma in Pediatric Patients: Results of the Multicenter Treatment Study SIOP-LGG 2004 Neuropediatrics 49(5): 314-323.

15. Nguyen TK, Perry J, Sundaram ANE, Detsky J, Maralani PJ, et al. (2019) Rescue bevacizumab following symptomatic pseudoprogression of a tectal glioma post-radiotherapy: a case report and review of the literature. J Neurooncol 143(3): 475-481.

16. Kihlström L, Lindquist C, Lindquist M, Karlsson B. (1994) Stereotactic radiosurgery for tectal low-grade gliomas. Acta Neurochir Suppl 62: 5557.

17. El Shehaby AM, Reda WA, Abdel Karim KM, Emad Eldin RM, Esene IN (2015) Gamma Knife radiosurgery for low-grade tectal gliomas. Acta Neurochir (Wien) 157(2): 247-256.

18. Sager O, Dincoglan F, Demiral S, Uysal B, Gamsiz H, et al. (2018) Radiation Therapy (RT) for Diffuse Intrinsic Pontine Glioma (DIPG) in Children. Arch Can Res 6(3): 14.

19. Sager O, Dincoglan F, Demiral S, Uysal B, Gamsiz H (2018) A concise review of immunotherapy for glioblastoma. Neuroimmunol Neuroinflammation 5: 25 .

20. Dincoglan F, Sager O, Uysal B, Demiral S, Gamsiz H, et al. (2019) Evaluation of hypofractionated stereotactic radiotherapy (HFSRT) to the resection cavity after surgical resection of brain metastases: A single center experience. Indian J Cancer 56(3): 202-206.

21. Demiral S, Dincoglan F, Sager O, Uysal B, Gamsiz H, et al. (2018) Contemporary Management of Meningiomas with Radiosurgery. Int J Radiol Imaging Technol 80(2): 187-190.

22. Dincoglan F, Sager O, Demiral S, Uysal B, Gamsiz H, et al. (2017) Radiosurgery for recurrent glioblastoma: A review article. Neurol Disord Therap 1: 1-5.

23. Demiral S, Dincoglan F, Sager 0, Gamsiz H, Uysal B, et al. (2016) Hypofractionated stereotactic radiotherapy (HFSRT) for who grade 1 anterior clinoid meningiomas (ACM). Jpn J Radiol 34(11): 730-737.

24. Dincoglan F, Beyzadeoglu M, Sager O, Demiral S, Gamsiz H, et al. (2015) Management of patients with recurrent glioblastoma using hypofractionated stereotactic radiotherapy. Tumori 101(2): 179-184.

25. Gamsiz H, Beyzadeoglu M, Sager O, Demiral S, Dincoglan F, et al. (2015) Evaluation of stereotactic body radiation therapy in the management of adrenal metastases from non-small cell lung cancer. Tumori 101(1): 98103.

26. Demiral S, Beyzadeoglu M, Sager O, Dincoglan F, Gamsiz H, et al. (2014) Evaluation of linear accelerator (linac)-based stereotactic radiosurgery (srs) for the treatment of craniopharyngiomas. UHOD - Uluslararasi Hematoloji-Onkoloji Dergisi 24: 123-129.

27. Dincoglan F, Sager O, Gamsiz H, Uysal B, Demiral S, et al. (2014) Management of patients with $\geq 4$ brain metastases using stereotactic radiosurgery boost after whole brain irradiation. Tumori 100(3): 302306.

28. Gamsiz H, Beyzadeoglu M, Sager O, Dincoglan F, Demiral S, et al. (2014) Management of pulmonary oligometastases by stereotactic body radiotherapy. Tumori 100(2): 179-183.

29. Sager O, Dincoglan F, Beyzadeoglu M (2015) Stereotactic radiosurgery of glomus jugulare tumors: Current concepts, recent advances and future perspectives. CNS Oncol 4(2): 105-114.

30. Sager O, Beyzadeoglu M, Dincoglan F, Gamsiz H, Demiral S, et al. (2014) Evaluation of linear accelerator-based stereotactic radiosurgery in the management of glomus jugulare tumors. Tumori 100(2): 184-188.

31. Sager O, Beyzadeoglu M, Dincoglan F, Uysal B, Gamsiz H, et al. (2014)
Evaluation of linear accelerator (LINAC)-based stereotactic radiosurgery (SRS) for cerebral cavernous malformations: A 15-year single-center experience. Ann Saudi Med 34(1): 54-58.

32. Demiral S, Beyzadeoglu M, Uysal B, Oysul K, Kahya YE, et al. (2013) Evaluation of stereotactic body radiotherapy (SBRT) boost in the management of endometrial cancer. Neoplasma 60(3): 322-327.

33. Dincoglan F, Beyzadeoglu M, Sager O, Uysal B, Demiral S, et al. (2013) Evaluation of linear accelerator-based stereotactic radiosurgery in the management of meningiomas: A single center experience. J BUON 18(3): 717-722.

34. Sager O, Beyzadeoglu M, Dincoglan F, Demiral S, Uysal B, et al. (2013) Management of vestibular schwannomas with linear accelerator-based stereotactic radiosurgery: A single center experience. Tumori 99(5): 617-622.

35. Dincoglan F, Sager O, Gamsiz H, Uysal B, Demiral S, et al. (2012) Stereotactic radiosurgery for intracranial tumors: A single center experience. Gulhane Med J 54(3): 190-198.

36. Dincoglan F, Sager O, Gamsiz H, Demiral S, Uysal B (2012) Management of arteriovenous malformations by stereotactic radiosurgery: A single center experience. UHOD-Uluslararasi Hematoloji-Onkoloji Dergisi 22: 107-112.

37. Dincoglan F, Beyzadeoglu M, Sager O, Oysul K, Sirin S (2012) Imageguided positioning in intracranial non-invasive stereotactic radiosurgery for the treatment of brain metastasis. Tumori 98(5): 630-635.

38. Sirin S, Oysul K, Surenkok S, Sager O, Dincoglan F, et al. (2011) Linear accelerator-based stereotactic radiosurgery in recurrent glioblastoma: A single center experience. Vojnosanit Pregl 68(11): 961-966.

39. Dincoglan F, Sager O, Demiral S, Gamsiz H, Uysal B, et al. (2019) Fractionated stereotactic radiosurgery for locally recurrent brain metastases after failed stereotactic radiosurgery. Indian J Cancer 56(2): 151-156.

40. Surenkok S, Sager O, Dincoglan F, Gamsiz H, Demiral S (2012) Stereotactic radiosurgery in pituitary adenomas: A single center experience. UHODUluslararasi Hematoloji-Onkoloji Dergisi 22: 255-260.

41. Sager O, Beyzadeoglu M, Dincoglan F, Oysul K, Kahya YE, et al. (2012) Evaluation of active breathing control-moderate deep inspiration breath-hold in definitive non-small cell lung cancer radiotherapy. Neoplasma 59(3): 333-340.

42. Dincoglan F, Beyzadeoglu M, Sager O, Oysul K, Kahya YE, et al. (2013) Dosimetric evaluation of critical organs at risk in mastectomized leftsided breast cancer radiotherapy using breath-hold technique. Tumori 99(1): 76-82.

43. Uysal B, Beyzadeoğlu M, Sager O, Dinçoğlan F, Demiral S, et al. (2013) Dosimetric evaluation of intensity modulated radiotherapy and 4-field 3-d conformal radiotherapy in prostate cancer treatment. Balkan Med J 30(1): 54-57.

44. Sager O, Beyzadeoglu M, Dincoglan F, Demiral S, Uysal B, et al. (2015) Adaptive splenic radiotherapy for symptomatic splenomegaly management in myeloproliferative disorders. Tumori 101(1): 84-90.

45. Sager O, Dincoglan F, Uysal B, Demiral S, Gamsiz H, et al. (2017) Splenic Irradiation: A Concise Review of the Literature. J App Hem Bl Tran 1(1): 101.

46. Sager O, Dincoglan F, Uysal B, Demiral S, Gamsiz H, et al. (2018) Evaluation of adaptive radiotherapy (ART) by use of replanning the tumor bed boost with repeated computed tomography (CT) simulation after whole breast irradiation (WBI) for breast cancer patients having clinically evident seroma. Jpn J Radiol 36(6): 401-406.

47. Sager O, Dincoglan F, Demiral S, Uysal B, Gamsiz H, et al. (2019) Breathing adapted radiation therapy for leukemia relapse in the breast: $\mathrm{A}$ case report. World J Clin Oncol 10(11): 369-374. 
48. Dincoglan F, Sager O, Demiral S, Beyzadeoglu M (2019) Incorporation of Multimodality Imaging in Radiosurgery Planning for Craniopharyngiomas: An Original Article. SAJ Cancer Sci 6: 103.

49. Demiral S, Sager O, Dincoglan F, Beyzadeoglu M (2019) Assessment of Computed Tomography (CT) And Magnetic Resonance Imaging (MRI) Based Radiosurgery Treatment Planning for Pituitary Adenomas. Canc Therapy \& Oncol Int J 13(2): 555857.

50. Beyzadeoglu M, Sager O, Dincoglan F, Demiral S (2019) Evaluation of Target Definition for Stereotactic Reirradiation of Recurrent Glioblastoma. Arch Can Res 7(1): 3.

51. Sager 0, Dincoglan F, Demiral S, Beyzadeoglu M (2019) Evaluation of Radiosurgery Target Volume Determination for Meningiomas Based on Computed Tomography (CT) And Magnetic Resonance Imaging (MRI). Cancer Sci Res Open Access 5(2): 1-4.

52. Dincoglan F, Sager O, Demiral S, Beyzadeoglu M (2019) Multimodality Imaging for Radiosurgical Management of Arteriovenous Malformations Asian Journal of Pharmacy, Nursing and Medical Sciences 7(1): 7-12.

53. Demiral S, Sager O, Dincoglan F, Beyzadeoglu M (2019) Assessment of target definition based on Multimodality imaging for radiosurgical Management of glomus jugulare tumors (GJTs). Cancer Ther Oncol Int J 15(2): 555909.

54. Sager O, Dincoglan F, Demiral S, Gamsiz H, Uysal B, et al. (2019) Utility of

ISSN: 2574-1241

DOI: $10.26717 /$ BJSTR.2020.27.004461

Omer sager. Biomed J Sci \& Tech Res

(C) This work is licensed under Creative

Submission Link: https://biomedres.us/submit-manuscript.php
Magnetic Resonance Imaging (Imaging) in Target Volume Definition for Radiosurgery of Acoustic Neuromas. Int J Cancer Clin Res 6: 119.

55. Sager 0, Dincoglan F, Demiral S, Gamsiz H, Uysal B, et al. (2019) Evaluation of the Impact of Magnetic Resonance Imaging (MRI) on Gross Tumor Volume (GTV) Definition for Radiation Treatment Planning (RTP) of Inoperable High-Grade Gliomas (HGGs). Concepts in Magnetic Resonance Part A Volume 2019.

56. Demiral S, Sager O, Dincoglan F, Uysal B, Gamsiz H, et al. (2018) Evaluation of Target Volume Determination for Single Session Stereotactic Radiosurgery (SRS) of Brain Metastases. Canc Therapy \& Oncol Int J 12(5): 555848.

57. Sager 0, Demiral S, Dincoglan F, Beyzadeoglu M (2020) Target Volume Definition for Stereotactic Radiosurgery (SRS) Of Cerebral Cavernous Malformations (CCMs). Canc Therapy \& Oncol Int J 15(4): 555917.

58. Dincoglan F, Demiral S, Sager O, Beyzadeoglu M (2020) Utility of Multimodality Imaging Based Target Volume Definition for Radiosurgery of Trigeminal Neuralgia: An Original Article. Biomed J Sci \& Tech Res 26(2): 19728-19732.

59. Beyzadeoglu M, Dincoglan F, Sager 0, Demiral S (2020) Evaluation of Target Volume Definition with Multimodality Imaging for Radiosurgery of Intracranial Germ Cell Tumors (GCTs): An Original Article. Asian Journal of Pharmacy, Nursing and Medical Sciences 08(02): 1-4.

$\begin{array}{ll}\text { BIOMEDICAL } & \text { Assets of Publishing with us } \\ \text { RESEARCHES } & \text { - Global archiving of articles } \\ & \text { - Immediate, unrestricted online access } \\ & \text { - Rigorous Peer Review Process } \\ & \end{array}$

